\title{
Assessment of the caffeine-containing beverages available in the local markets, and development of a real energy drink based on the date fruit
}

\author{
Heba Sayed MOSTAFA ${ }^{1 *}$
}

\begin{abstract}
Globally, tea, coffee, soft and energy drinks are daily consumed as a source of caffeine. Energy drinks gained a great public and scientific issues, thus this study assessed the caffeine content in some caffeine-containing beverages. Given the increasing demand for newly formulated healthy drinks, the date fruit (Phoenix dactylifera L. cv. Siwi) was used to develop a fruit-energy drink as an alternative for the energy drinks. Results displayed that the coffee addition even to $80 \mathrm{mg} / 250 \mathrm{~mL}$, did not significantly altered the acidity of the final developed drink. It contained rapidly metabolized sugars of $27.86 \mathrm{~g} / 250 \mathrm{~mL}$ without added sugar and was slightly neutral ( $\mathrm{pH}=6.04$ ). The sensory assessment revealed that the added coffee (up to $320 \mathrm{mg} / \mathrm{L}$ ) enhanced its aroma and taste but negatively affected the color. The high naturally occurring vitamins and minerals content and the gross energy; made this drink a super energy drink to fulfill the needs of athletes. Some of the tested local caffeine-containing beverages contained caffeine higher than those mentioned on the product label. On the other side, Turkish coffee brews contained 1.99-9.46 mg/g and the instant coffees had provided the highest ever caffeine $(24.71 \mathrm{mg} / \mathrm{g})$, such that their daily consumption should be alarmed.
\end{abstract}

Keywords: ready-to-drink; coffee; fruit-based drink; athletes.

Practical Application: Production of a fruit-based energy drink with many health benefits.

\section{Introduction}

In the recent years, an increasing number of caffeinecontaining beverages' consumers have been reported due to the overpopulation and long and inconvenient working hours (Jahrami et al., 2020). Caffeine is an alkaloid that naturally synthesizes in the leaves of tea, seeds of coffee and fruit of cocoa and kola trees, or added to the energy drinks. It has gained more attention due to its physiological effect (Enyart et al., 2020). For example, it activates the nervous system and consequence can temporarily increases the risk of miscarriage, disrupts sleep, causes vasoconstriction and increases the risk for myocardial ischemia (Temple et al., 2017), and upsurges the blood flow and blood pressure (de Paula \& Farah, 2019).

Due to those potential effects of caffeine-containing drinks, it is important to ascertain their exact caffeine content (Al-Bratty et al., 2020). Most company-produced drinks provide details on the content of caffeine, but the issue occurs with the alkaloid content of tea and coffee (Sanchez, 2017). The caffeine content of caffeine containing drinks are regularly tracked by the United State Food and Drug Administration (US FDA), allowing a maximum limit of $200 \mathrm{mg}$ /day with no raising concerns for adults (Sanchez, 2017). In Egypt, most studies (Tayel et al., 2018; El-Nimr et al., 2019) concluded that, the intake of caffeinecontaining drinks among the population was very high and exceeded the safe level ( $\geq 200 \mathrm{mg} /$ day), as $61.4 \%$ are drinking at least one caffeinated drink per day.

Energy drinks contain a quantity of substances including guarana (contains caffeine, teobromine, and teofiline), taurine (an amino acid), ginseng extract, glucuronolactone (a glucose metabolite), yohimbine, ephedra, Ginkgo biloba, and sugars (Higgins et al., 2015). Regular energy drinks consumption have been correlated with several medical problems including seizures, anxiety, hallucinations, arrhythmias and other cardiovascular complications which prompted review of the safety of these beverages (Al-Bratty et al., 2020).

The development of blended drinks is a successful way to boost the nutritional value of conventional products or to overcome the problems associated by current products (Márquez Cardozo et al., 2017). A number of researchers have been created alternatives of energy drinks based on fruits. For example, Márquez Cardozo et al. (2017) formulated mango energy drink containing caffeine at a concentration of $30 \mathrm{mg} / 100 \mathrm{~mL}$, though Nowak \& Goslinski (2020) evaluated various fruit energy drinks containing pineapple, apple, strawberry, raspberry, carrot and pomegranate juice.

More than 2000 varieties of dates (Phoenix dactylifera L.) are grown worldwide, and Egypt is the world's leading producer with 1562171 Ton in 2018 (Food and Agriculture Organization of the United Nations, 2018). The chemical composition of the date fruit mainly differs by the cultivar, ripening stage, the postharvest and growing conditions, ... etc (Nadir et al., 2017). The major component of the date fruit is carbohydrate (sucrose, glucose and fructose), which may reach more than $70 \% \mathrm{dw}$ and provide net gross energy from 352 to $425 \mathrm{kcal} / 100 \mathrm{~g}$ (Chandrasekaran \& Bahkali, 2013). Date fruit is also a good fiber source and contains many essential vitamins and minerals such as iron, calcium and magnesium (Nadir et al., 2017). Many investigators 
(Eid et al., 2014; Al-Shawyeh, 2019) documented the strong antioxidant, anti-inflammatory, hepatoprotective and anticancer activity of different dates and their products.

There was a shortage of research into the precise amount of caffeine in the available caffeine containing beverages in Egypt. We therefore aimed to evaluate the caffeine level in some of these items. However, in order to test the acceptance of a healthy energy drink, the key goal is to create and evaluate a real energy drink based on the date fruit.

\section{Materials and methods}

\subsection{Samples collection}

Six brands of cola-drinks, four regular: Big cola, Pepsi, Coke and Sina cola, and two diet brands: Pepsi diet and Cola zero (coded C1, C2, C3, C4, C5 and C6) as well as five kinds of energy drinks (Coca cola energy, Red bull regular and diet, HYPE and Power horse) coded E1, E2, E3, E4 and E5; were purchased randomly from local supermarkets in January 2020. Eight brands of black tea (Dilmah, Arousa, El-Gamhouriah, Lipton, Ahmad Tea, Rabea, Tetley and Twinings) coded T1, T2, T3, T4, T5, T6, T7 and T8, 3 brands of green tea (Lipton, Twinings and Isis) coded G1, G2 and G3 as well as twelve different coffee powders, six freshly roasted in varying degrees; and the other six were espresso, decaffeinated and instant coffees also obtained from the supermarkets and coffee shops. All the unopened beverages cans or bottles were kept at room temperature till the examination. The fresh roasted coffees were analyzed within one week. All samples were analyzed in triplicate.

\subsection{Standard preparation}

$100 \mathrm{mg} / \mathrm{L}$ caffeine (Sigma-Aldrich, St. Louis, USA) stock solution was prepared by dissolving caffeine powder in pure dichloromethane (Sigma-Aldrich, St. Louis, USA). Working solutions ranging from 10 to $60 \mathrm{mg} / \mathrm{L}$ were prepared from the stock solution in the same solvent. The absorbance of each concentration was measured by UV-Spectrophotometer (Unico-UV2000, USA) at $270 \mathrm{~nm}$ (Belay et al., 2008). Caffeine content was calculated from the linear regression equation where the $\mathrm{R}^{2}=0.9987$.

\subsection{Samples preparation}

\section{Soft and energy drinks}

The approach of Khalid et al. (2016) was applied to determine the caffeine content in soft and energy drinks with some modifications. One to three $\mathrm{mL}$ from each can was neutralized by mixing with equal volume of saturated sodium bicarbonate solution (8\%). The caffeine of the mixture was extracted by dichloromethane, and then completed to a specific volume of $20 \mathrm{~mL}$. Using a glass separating funnel $(250 \mathrm{~mL})$; the lower layer was withdrawn and $A_{270}$ was read by UV-Spectrophotometer.

\section{Tea and coffee}

The extraction of black and green tea was carried out as described by Camargo \& Toledo (1999) with some modifications. One $g$ of black or green tea powder had been extracted with
$10 \mathrm{~mL}$ of boiling distilled water. The contents of caffeine in a serving cup with one immersed tea bag $(2 \mathrm{~g})$ were also calculated. Whereas, coffee brews from different roasted coffees (light, medium and dark or Arabian) were prepared by mixing $1 \mathrm{~g}$ with $100 \mathrm{~mL}$ of distilled water at $30{ }^{\circ} \mathrm{C}$, and left to boil in a double jacket boiler for $30 \mathrm{sec}$. Espresso or decaffeinated coffee brew was prepared from $16 \mathrm{~g}$ of finely ground roasted coffee with a volume of approximately $100 \mathrm{~mL}$ water $\left(92^{\circ} \mathrm{C}\right)$ using an espresso coffee machine (EC221R, Delonghi) under a pressure of $1.5 \mathrm{bar}$ for $30 \mathrm{sec}$. American coffee brew was made from $60 \mathrm{~g}$ of ground roasted coffee with a volume of $1.125 \mathrm{~L}$ distilled water using a filter coffeemaker (KF147, Braun). After cooling to the room temperature $30^{\circ} \mathrm{C}$, the tea extract or coffee brew was filtered (Whatman filter paper, No.1). Instant coffee brews were prepared as tea extracts. One $\mathrm{mL}$ of any extract was mixed with dichloromethane and completed to a specific volume of $20 \mathrm{~mL}$. Using a glass separating funnel $(250 \mathrm{~mL})$; the lower layer was withdrawn and $A_{270}$ was read by UV-Spectrophotometer.

\subsection{Date-based energy drink preparation}

Date fruit paste (Phoenix dactylifera L. cv. Siwi, 00012432) was obtained from the local market, blended with distilled water $(1: 2 \mathrm{w} / \mathrm{v})$ and then diluted to obtain a date juice at $18 \mathrm{Brix}$ (Food and Agriculture Organization of the United Nations, 2005). Date juice was pasteurized at $90{ }^{\circ} \mathrm{C}$ for $2 \mathrm{~min}$ in sealed glass bottles $(250 \mathrm{~mL})$; cooled then boiled brewed coffee (from light plain coffee) ( $\mathrm{pH} 5.0)$ was aseptically added to reach a caffeine concentration of $20,40,60$ or $80 \mathrm{mg} /$ bottle equivalent to $80,160,240$ and $320 \mathrm{mg} / \mathrm{L}$. This approach was applied to maintain the original flavor of coffee and to eliminate changes in the flavor caused by mixing date and coffee from the beginning (Ikeda et al., 2018). Physico-chemical and sensory analysis of the developed beverage samples was carried out.

\section{Physico-chemical analysis}

The acidity of each diluted sample was determined by titration with $\mathrm{NaOH}(0.1 \mathrm{~N})$ and calculated based on acetic acid, the abundant acid (Association of Official Analytical Chemists, 2000). The $\mathrm{pH}$ was measured by $\mathrm{pH}$-meter (301, Orion Research Incorporated, Boston, USA). Total soluble solids (TSS) were measured using a hand refractometer (DR-A1, Atago, Japan).

The concentration of reducing sugars in each sample was estimated by 3, 5-dinitrosalysilic acid reagent (Sigma Aldrich, St. Louis, USA) according to the method of Miller (1959). The absorbance was assessed at $540 \mathrm{~nm}$ (UV-Spectrophotometer, Unico-UV2000, USA) in parallel with the distilled water as a blank. Total sugars content was estimated by anthrone reagent (Sigma Aldrich, St. Louis, USA) at $630 \mathrm{~nm}$ according to Ludwig \& Goldberg (1956). The standard curve for both measurements was prepared with different concentrations of glucose $(0.01-0.1 \mathrm{mg} / \mathrm{mL})$.

\section{Sensory analysis}

The acceptance test was carried out by panel of 50 non-trained panelists aged 20-45 years from staff and student members of the Food Science Department, Faculty of Agriculture, Cairo University, Egypt. The oral informed consent was taken from all 
participants. The test was conducted with a hedonic rating system using 9-point hedonic scale, where 9 meant liked extremely and 1 meant dislike extremely. The chilled samples $\left(4^{\circ} \mathrm{C}\right)$ were served in $50 \mathrm{~mL}$ plastic cups for testing aroma, taste, color, consistency and the overall acceptance (Nguyen \& Chuyen, 2020).

\subsection{Statistical analysis}

Data in triplicates was statistically analyzed by one way analysis of variance (ANOVA) and the Duncan's multiple range was used compare the means at $p \leq 0.05$. The results are presented as means with standard deviations. The Costat software has been used for all measurements of variance.

\section{Results and discussion}

\subsection{Caffeine content of soft and energy drink samples}

All the soft cola samples collected in this study have undisclosed caffeine content in their label. The caffeine content of the soft regular and diet drinks is therefore estimated and listed in Table 1. The caffeine ranged from 0.02 to $0.32 \mathrm{mg} / \mathrm{mL}$ and the highest value was contained in $\mathrm{C} 3$ sample, while the cheapest national sample (C4) contains the lowest caffeine content $(5.08 \mathrm{mg} / \mathrm{can})$ with a significant differences $(p \leq 0.05)$. The United States Department of Agriculture-USDA (2018) nutrient data base estimated an average caffeine level of $86.12 \mathrm{mg} / 250 \mathrm{~mL}$ for regular cola beverages that exceeds the estimated in this study. In diet cola products, C5 contained a higher caffeine level of $8.3 \%$ relative to the regular cola from the same manufacturer (C2). Whereas, Cola zero (C6) was $71.9 \%$ lower than that of the same brand (C3). Data of the United States Department of Agriculture (2018) reported an average of $33.81 \mathrm{mg} / 250 \mathrm{~mL}$ of caffeine in diet soft drinks which was also higher than the values recorded in this study. Sanchez (2017) observed a 25\% rise in caffeine content in all Spanish diet-cola soft drinks compared to regular colas.

According to the label claims, the amount of caffeine present in all energy drinks tested was $320 \mathrm{mg} / \mathrm{L}$ which is equivalent to $80 \mathrm{mg} / 250 \mathrm{~mL}$. The average levels of this alkaloid really existing in each energy drink are tabulated in Table 1 . Their caffeine contents ranged from 45.0 to $137.5 \mathrm{mg} / \mathrm{can}$. With the exception of E2 and E4 brands, the other brands displayed substantially different caffeine content. Sample (E5) had more caffeine than any energy or soft drink. Both E1 and E5 samples were respectively 25.0 and $71.9 \%$ higher than those mentioned on the product label, while the other items did not exceed this limit. Generally, the concentration of caffeine in energy drinks was substantially higher than that of soft drinks that also reported by other researchers (Sanchez, 2017; Tayel et al., 2018). That can be explained by the fact that energy drinks have incorporated caffeine, while cola in soft drinks is the natural source of caffeine.

\subsection{Caffeine content of tea and coffee samples}

Table 2 indicates the levels of caffeine in eight black and three green teas nationally available in the Egyptian markets as calculated in powder and in the serving cup $(100 \mathrm{~mL})$. The results show that, T2 sample followed by T4 was significantly the richest natural tea source of caffeine. Three out of the 8-national black tea brands (T3, T6 and T8) were found to be in the average United States Department of Agriculture (2018) caffeine level $(40 \mathrm{mg} / 2 \mathrm{~g})$. The other five tea brands were quite different from that in the USDA database. Tfouni et al. (2018) observed a quantity of caffeine ranged from 4.0 to $6.8 \mathrm{mg}$ in a cup $(100 \mathrm{~mL})$ of mate tea, and 9.6-14.9 mg/cup of black Brazilian tea. On the other side, the caffeine content of green tea samples was lower than that of black tea. The average caffeine content in green tea samples of the same brand was lower by $11.3 \%$ and $22.9 \%$ as seen in G1 and G2 samples, respectively. That primarily attributed to the microbial fermentation process of green tea leaves which may increase the caffeine content up to 56.84\% (Tfouni et al., 2018).

The most conventional way to prepare coffee in Egypt is the Turkish way and the exact caffeine concentration in seven coffee brews (samples 1-7) prepared by this process is summarized in Table 3. The findings confirm that the caffeine content in these items ranged between $1.99-9.46 \mathrm{mg} / \mathrm{g}$ dry coffee. That variation may be influenced by the roasting degree. The highest amount of this alkaloid was found in light coffee containing cardamom as a flavor of $9.46 \mathrm{mg} / \mathrm{g}$ dry coffee. Contrary, Arabian coffee contains the lowest caffeine level $(1.99 \mathrm{mg} / \mathrm{g})$ that equivalent to some tea brands (T3). In general, the caffeine content steadily decreased by increasing the roasting degree in both plain coffee and coffee with cardamom. This may be clarified as the caffeine content is not drastically altered during coffee roasting due to its thermal stability, but minor losses can occur due to sublimation (de Paula \& Farah, 2019). The caffeine content in the literature ranged between 0.7 and $1.6 \mathrm{~g} / 100 \mathrm{~g}$ of roasted coffees (Pilipczuk et al., 2015; de Paula \& Farah, 2019). On the other side, instant coffee (Gold brand) contained the highest average caffeine concentration $(24.71 \mathrm{mg} / \mathrm{g})$ in this study, preceded by the original instant coffee $(14.71 \mathrm{mg} / \mathrm{g})$. These findings were consistent with the manufacturer data $(50-90 \mathrm{mg} / 2 \mathrm{~g}$ ) available on their website. The high dry content of caffeine in this form of coffees (soluble coffee) is the result of the use of Robusta

Table 1. The caffeine content of different soft and energy drinks (Mean \pm SD).

\begin{tabular}{|c|c|c|c|c|c|c|}
\hline \multirow{2}{*}{ No. } & \multirow{2}{*}{ Soft drink code } & \multicolumn{2}{|c|}{ Caffeine content } & \multirow{2}{*}{ Energy drink code } & \multicolumn{2}{|c|}{ Caffeine content } \\
\hline & & $\mathrm{mg} / \mathrm{mL}$ & $\mathrm{mg} / \mathrm{can}(250 \mathrm{~mL})$ & & $\mathrm{mg} / \mathrm{mL}$ & $\mathrm{mg} / \mathrm{can}(250 \mathrm{~mL})$ \\
\hline 1 & $\mathrm{C} 1$ & ${ }^{\star} 0.12^{\mathrm{bc}} \pm 0.01$ & $30.0^{b c} \pm 2.41$ & $\mathrm{E} 1$ & $0.40^{\mathrm{b}} \pm 0.05$ & $99.9^{\mathrm{b}} \pm 1.84$ \\
\hline 2 & $\mathrm{C} 2$ & $0.12^{b c} \pm 0.00$ & $30.0^{b c} \pm 1.28$ & E2 & $0.28^{c} \pm 0.02$ & $70.0^{c} \pm 6.93$ \\
\hline 3 & $\mathrm{C} 3$ & $0.32^{\mathrm{a}} \pm 0.01$ & $80.0^{\mathrm{a}} \pm 3.47$ & E3 & $0.18^{\mathrm{d}} \pm 0.00$ & $44.9^{\mathrm{d}} \pm 1.47$ \\
\hline 4 & $\mathrm{C} 4$ & $0.02^{\mathrm{d}} \pm 0.02$ & $5.0^{\mathrm{d}} \pm 0.59$ & $\mathrm{E} 4$ & $0.30^{c} \pm 0.00$ & $74.9^{c} \pm 1.32$ \\
\hline 5 & C5 & $0.13^{\mathrm{b}} \pm 0.01$ & $32.5^{\mathrm{b}} \pm 2.29$ & E5 & $0.55^{\mathrm{a}} \pm 0.04$ & $137.5^{\mathrm{a}} \pm 3.90$ \\
\hline 6 & C6 & $0.09^{c} \pm 0.01$ & $22.5^{c} \pm 2.55$ & & & \\
\hline
\end{tabular}

${ }^{\star}$ Means followed by different superscripts (within columns) are significantly different $(p \leq 0.05)$. 
Table 2. The caffeine content of different black and green tea brands (Mean $\pm \mathrm{SD})$.

\begin{tabular}{|c|c|c|c|}
\hline \multirow[b]{2}{*}{ No. } & \multirow[b]{2}{*}{ Sample code } & \multicolumn{2}{|c|}{ Caffeine content } \\
\hline & & $\mathrm{mg} / \mathrm{g}$ & $\begin{array}{l}\text { mg/cup } \\
\text { (100 mL) }\end{array}$ \\
\hline \multicolumn{2}{|c|}{ Black Tea } & & \\
\hline 1 & $\mathrm{~T} 1$ & $\star 2.26^{\mathrm{bc}} \pm 0.07$ & $45.23^{\mathrm{bc}} \pm 1.52$ \\
\hline 2 & $\mathrm{~T} 2$ & $2.82^{\mathrm{a}} \pm 0.25$ & $56.36^{\mathrm{a}} \pm 5.05$ \\
\hline 3 & T3 & $1.93^{\mathrm{def}} \pm 0.01$ & $38.55^{\mathrm{def}} \pm 0.29$ \\
\hline 4 & $\mathrm{~T} 4$ & $2.50^{\mathrm{b}} \pm 0.05$ & $49.99^{\mathrm{b}} \pm 1.15$ \\
\hline 5 & T5 & $2.21^{\mathrm{bcd}} \pm 0.01$ & $44.28^{\mathrm{bcd}} \pm 0.24$ \\
\hline 6 & T6 & $1.78^{\mathrm{ef}} \pm 0.16$ & $35.56^{\mathrm{ef}} \pm 0.24$ \\
\hline 7 & $\mathrm{~T} 7$ & $2.06^{\text {cde }} \pm 0.19$ & $41.12^{\text {cde }} \pm 3.83$ \\
\hline 8 & $\mathrm{~T} 8$ & $1.87^{\mathrm{ef}} \pm 0.18$ & $37.40^{\mathrm{ef}} \pm 3.73$ \\
\hline \multicolumn{2}{|c|}{ Green Tea } & & \\
\hline 9 & G1 & $2.22^{\mathrm{bcd}} \pm 0.00$ & $44.35^{\mathrm{bcd}} \pm 0.14$ \\
\hline 10 & G2 & $1.44^{\mathrm{g}} \pm 0.02$ & $28.83^{g} \pm 0.49$ \\
\hline 11 & G3 & $1.68^{\mathrm{fg}} \pm 0.00$ & $33.58^{\mathrm{fg}} \pm 0.04$ \\
\hline
\end{tabular}

${ }^{*}$ Means followed by different superscripts (within columns) are significantly different $(p \leq 0.05)$.

Table 3. The caffeine content of different coffee items (Mean \pm SD).

\begin{tabular}{|c|c|c|c|}
\hline \multirow[b]{2}{*}{ No. } & \multirow[b]{2}{*}{ Sample } & \multicolumn{2}{|c|}{ Caffeine content } \\
\hline & & $\mathrm{mg} / \mathrm{g}$ & $\begin{array}{c}\mathrm{mg} / \mathrm{cup} \\
(5 \mathrm{~g} / 50 \mathrm{~mL})\end{array}$ \\
\hline 1 & Light plain coffee & ${ }^{\star} 7.37^{\mathrm{d}} \pm 0.18$ & $73.67^{\mathrm{d}} \pm 1.88$ \\
\hline 2 & Medium plain coffee & $7.17^{\mathrm{d}} \pm 0.23$ & $71.67^{\mathrm{d}} \pm 2.35$ \\
\hline 3 & Dark plain coffee & $5.44^{\mathrm{ef}} \pm 0.08$ & $54.38^{\mathrm{ef}} \pm 0.88$ \\
\hline 4 & $\begin{array}{l}\text { Light coffee containing } \\
\text { cardamom }(10 \%)\end{array}$ & $9.46^{c} \pm 0.03$ & $94.59^{c} \pm 0.35$ \\
\hline 5 & $\begin{array}{l}\text { Medium coffee containing } \\
\text { cardamom }(10 \%)\end{array}$ & $7.53^{\mathrm{d}} \pm 0.16$ & $75.31^{\mathrm{d}} \pm 1.68$ \\
\hline 6 & $\begin{array}{l}\text { Dark coffee containing } \\
\text { cardamom }(10 \%)\end{array}$ & $5.61^{\mathrm{e}} \pm 0.43$ & $56.05^{\mathrm{e}} \pm 4.30$ \\
\hline 7 & Arabian coffee (Arabiaca) & $1.99^{\mathrm{h}} \pm 0.00$ & $19.87^{\mathrm{h}} \pm 0.07$ \\
\hline 8 & Espresso & $5.06^{\mathrm{f}} \pm 0.08$ & $50.64^{\mathrm{f}} \pm 0.88$ \\
\hline 9 & Decaffeinated coffee & $0.54^{\mathrm{i}} \pm 0.00$ & $5.43^{\mathrm{i}} \pm 0.01$ \\
\hline 10 & American coffee & $2.56^{g} \pm 0.02$ & $25.63^{g} \pm 0.27$ \\
\hline 11 & Instant coffee & $14.71^{\mathrm{b}} \pm 0.44$ & $147.08^{\mathrm{b}} \pm 4.41$ \\
\hline 12 & Instant coffee (Gold) & $24.71^{\mathrm{a}} \pm 0.14$ & $247.08^{\mathrm{a}} \pm 1.47$ \\
\hline
\end{tabular}

${ }^{\star}$ Means followed by different superscripts (within columns) are significantly different $(p \leq 0.05)$.

coffee beans that are extracted by pressure with water at high temperatures $\left(\geq 200^{\circ} \mathrm{C}\right)$ to obtain a coffee extract with around $15 \%$ solids, then filtered and dried (Sanchez, 2017). The caffeine content in decaffeinated form of coffee reached $0.54 \mathrm{mg} / \mathrm{g}$ that equal 5.43 per serving $(50 \mathrm{~mL})$. That was higher than recorded in decaffeinated ground roasted coffees purchased in coffee shops in USA $3.7 \mathrm{mg} / 100 \mathrm{~mL}$ (Bravo et al., 2012).

\subsection{The development of date-based energy drink}

In this work, a non-alcoholic drink consists mainly of date fruit and flavored by coffee brew was developed. The drink combines the high sugar percentage of date (energy source) and the natural caffeine with the favored flavor of the coffee. The developed product was analyzed and its physical and chemical attributes are shown in Table 4. Results displayed that the coffee addition even to $80 \mathrm{mg} / 250 \mathrm{~mL}$, did not significantly altered the acidity or $\mathrm{pH}$ of the final drink. $\mathrm{pH}$ of the drink was slightly neutral (ranged 6.26-6.04) that may be due to the low percent of vitamin C in both date and coffee (Vignoli et al., 2011; Ahmed et al., 2014). Most of fruit energy drinks have a $\mathrm{pH}$ ranged between 2.32-3.60 (Clapp et al., 2019; Nowak \& Goslinski, 2020) while it was 2.45 in created mango energy drink of Márquez Cardozo et al. (2017). With reference to the total soluble solids of the prepared drink; it started from $18 \%$ (control) then decreased by increasing the added coffee reaching $16.33 \%$ in drink containing $80 \mathrm{mg}$ caffeine $/ 250 \mathrm{~mL}$ due to the added coffee brew (7.0\%) that diluted the created juice.

In regards to the reducing sugars content, the control samples (no coffee) contained $13.49 \%$, this percentage declined gradually by coffee addition to the least value of $11.14 \%$. One bottle $(250 \mathrm{~mL})$ of the developed drink provides total sugars between 33.46 to $38.74 \mathrm{~g}$ depending on the coffee content. Although coffee contains sucrose but it is broken down during the roasting process to produce furans that explain the sweet aromatics, caramel and burnt aromas of coffee brew (Seninde \& Chambers, 2020). Nadir et al. (2017) determined the total and reducing sugar content of some Egyptian date varieties juices and it was in the range of 11.71 to $12.22 \%$ and 8.95 to $10.51 \% \mathrm{dw}$, respectively. The estimated sugars concentration in this study is in the range that declared in many fruit energy drinks containing sugars (27.5-52.5 g/250 mL) (Nowak \& Goslinski, 2020). The advantage is that all sugars come from the date fruit with no sugar added. The progressive decrease of the total soluble solids, reducing and a total sugar is the result of the dilution of the TSS by the coffee brews addition. Consideration should be taken with a regular consumption of the invented drink due to the risk of excessive sugar intake which is conductive to overweight and obesity (Nowak \& Goslinski, 2020).

\subsection{Consumer acceptance of the developed energy drink}

The sensory analysis of the developed drink by the 9-point hedonic scale showed great variations of all samples $(p \leq 0.05)$ in the preference of the panelists with its individual characteristics (Figure 1). The samples containing coffee had higher points for aroma, and taste than the control sample. Whereas, the control sample (no coffee) exhibited higher grades for color than the other samples at $p \leq 0.05$. The sensory scores of both aroma and taste increased $(p \leq 0.05)$ by increasing the coffee content of the served drink. As a result, the sample containing $320 \mathrm{mg} / \mathrm{L}=80 \mathrm{mg}$ per serving $(250 \mathrm{~mL})$ got the highest scores of aroma and taste of the sensory evaluation panel. Since the coffee brew had a significant amount of volatile and non-volatile chemical compounds that are produced as a result of Maillard, pyrolysis and Strecker degradation reactions during coffee roasting and contribute significantly to its perceived sensory characteristics (Melo Pereira et al., 2019). Consequently, the higher concentration of those compounds in the date drink sample of $320 \mathrm{mg} / \mathrm{L}$ caffeine may be the reason of the high scores for the taste and aroma. Based on the consistency of the samples, there are no major deviations $(p \geq 0.05)$ between all the tested samples, while the most liked was the control (no coffee). That 
Table 4. Physico-chemical attributes of the developed date-based energy drink (Mean \pm SD).

\begin{tabular}{cccccc}
\hline $\begin{array}{c}\text { Date-based energy drink } \\
\text { sample }\end{array}$ & $\mathrm{pH}$ & Acidity $(\%)$ & TSS $(\%)$ & $\begin{array}{c}\text { Reducing sugar } \\
(\mathrm{g} / 250 \mathrm{~mL})\end{array}$ & $\begin{array}{c}\text { Total sugar } \\
(\mathrm{g} / 250 \mathrm{~mL})\end{array}$ \\
\hline $\begin{array}{c}\text { Caffeine concentration } \mathbf{~ m g / L} \\
0 \text { (Control) }\end{array}$ & $\star^{6} 6.26^{\mathrm{a}} \pm 0.07$ & $0.19^{\mathrm{a}} \pm 0.03$ & $18.00^{\mathrm{a}} \pm 0.14$ & $33.73^{\mathrm{a}} \pm 0.00$ & $40.50^{\mathrm{a}} \pm 0.01$ \\
80 & $6.20^{\mathrm{ab}} \pm 0.09$ & $0.18^{\mathrm{ab}} \pm 0.00$ & $17.81^{\mathrm{ab}} \pm 0.13$ & $32.26^{\mathrm{b}} \pm 0.00$ & $38.74^{\mathrm{b}} \pm 0.02$ \\
160 & $6.15^{\mathrm{ab}} \pm 0.00$ & $0.17^{\mathrm{bc}} \pm 0.01$ & $17.31^{\mathrm{bc}} \pm 0.28$ & $30.80^{\mathrm{c}} \pm 0.01$ & $36.98^{\mathrm{c}} \pm 0.01$ \\
240 & $6.09^{\mathrm{ab}} \pm 0.02$ & $0.17^{\mathrm{bc}} \pm 0.00$ & $16.82^{\mathrm{c}} \pm 0.16$ & $29.33^{\mathrm{d}} \pm 0.09$ & $35.22^{\mathrm{d}} \pm 0.00$ \\
320 & $6.04^{\mathrm{b}} \pm 0.03$ & $0.16^{\mathrm{c}} \pm 0.01$ & $16.33^{\mathrm{d}} \pm 0.04$ & $27.86^{\mathrm{e}} \pm 0.03$ & $33.46^{\mathrm{e}} \pm 0.01$ \\
\hline
\end{tabular}

${ }^{*}$ Means followed by different superscripts (within columns) are significantly different $(p \leq 0.05)$.

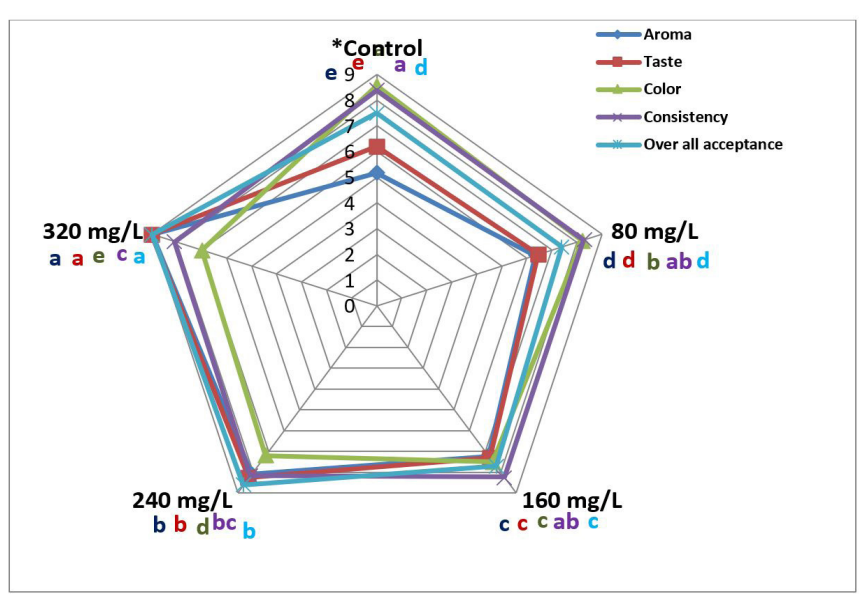

Figure 1. Mean sensory scores of the developed date-based energy drink samples containing coffee at different caffeine concentration $(\mathrm{mg} / \mathrm{L})$ using a 9 -point hedonic scale $(1=$ dislike extremely and $9=$ like extremely). Control $=$ no added coffee. ${ }^{\star}$ Different letters are significantly different at $p \leq 0.05$.

may be explained by the effect of coffee addition on the total soluble solids percentage of the prepared samples (Table 4).

Although flavor may be the most important factor driving consumers' choice of food products (Chareonthaikij et al., 2016), color is also known to influence people's perception of flavor in various beverages. Consumers often use color to evaluate foods before making a final decision to buy or consume that food (Chonpracha et al., 2019). The brown color of coffee brews also contributed to the sensory score in this study. That was obviously shown as the color sensory attribute of all date drink decreased significantly $(p \leq 0.05)$ at high percentage of coffee reaching a very low sensory point for color (6.98) of the drink sample containing $320 \mathrm{mg}$ caffeine/L. Results also showed that the dark color of the coffee containing samples did not affect the consumers' acceptance of that drink. These findings indicated that fortification of date juice with coffee brew could be reached the maximum caffeine limit of $320 \mathrm{mg} / \mathrm{L}$ without rejection of the beverage by consumers.

Although the literature on date beverages is lacking, but in general the date juice prepared from different date cultivars were found to be acceptable by consumers (Nadir et al., 2017). The main advantages of the formulated drink are that it has a high percentage of sugars that are readily absorbed by the human body and rapidly provide the consumer with energy. From an economic point of view, there is no added sugar. In addition, the maximum caffeine content of that drink $(320 \mathrm{mg} / \mathrm{L})$ did not exceed the limit of the energy drinks purchased. Also, there was no guarana and tourine in our drink that proved their side effects (Higgins et al., 2015). On the fact that low $\mathrm{pH}$ drinks $(<5.5)$ were associated with the dental erosion (Clapp et al., 2019), this beverage ( $\mathrm{pH}$ 6.04) could not lead to this dental problem. The advantage of this drink is supposed to provide consumers with many antioxidants and phenolic compounds (i.e. rutin and ellagic acid) from the date fruit and (caffeic acid) from coffee that have several health benefits such as anticancer and anti-alzehimer effects (Al-Shawyeh, 2019; Krol et al., 2020). Furthermore, the high content of vitamins such as thimine $\mathrm{HCl} \mathrm{B} 1$, riboflavin $\mathrm{B} 3$, pantothenic acid $\mathrm{B} 5$, pyridoxine $\mathrm{HCl}$ B6, folic acid B9 and cyanocobalamine, B12 (Aslam et al., 2013) and minerals (i.e. iron, calcium and magnesium) of date fruit also naturally make this drink a super beverage to fulfill the needs of athletes (Volpe, 2007). Added coffee is a natural source of caffeine and antioxidants as well as many non-volatile and volatile compounds (e.g. pyrazines and pyridines) (Seninde \& Chambers, 2020). These volatiles can be used to build different consumer segments that would allow for a more reliable and efficient way of meeting their necessities.

\section{Conclusion}

In conclusion, the best way for universal access to caffeine data is to put values on food labels so that consumers can be informed about the particular amount of caffeine they are drinking. Consumers would be also able to compare products instantly, enabling them to make more conversant acquiring decisions. With regard to the public health and food safety, the consumption of energy drink items as a source of illusion energy should be considered. Alternatively, the invented energy fruit-based drink flavored with coffee that does not surpass the limits of energy drinks, and based on the perceptual assessment could be purchased and consumed as it gained high degree of consumer acceptance. Further studies will be undertaken to investigate the bioactive constituents and the vitamins content of the developed drink and its health benefits as anti-oxidation and anticancer effect.

\section{References}

Ahmed, J., Al-Jasass, F. M., \& Siddiq, M. (2014). Date fruit composition and nutrition. In M. Siddiq, S. M. Aleid \& A. A. Kader (Eds.), Dates: postharvest science, processing technology and health benefits (1st ed., pp. 261-283). Chichester: John Wiley \& Sons.

Al-Bratty, M., Alhazmi, H. A., Rehman, Z., Javed, S. A., Ahsan, W., Najmi, A., Khuwaja, G., Makeen, H. A., \& Khalid, A. (2020). 
Determination of caffeine content in commercial energy beverages available in Saudi Arabian market by gas chromatography-mass spectrometric analysis. Journal of Spectroscopy, 2020, 3716343. http://dx.doi.org/10.1155/2020/3716343.

Al-Shawyeh, H. (2019). Date palm (Phoenix dactylifera, L.) fruit as potential antioxidant and antimicrobial agents. Journal of Pharmacy \& Bioallied Sciences, 11(1), 1-11. http://dx.doi.org/10.4103/JPBS. JPBS_168_18. PMid:30906133.

Aslam, J., Khan, S. H., \& Khan, S. A. (2013). Quantification of water soluble vitamins in six date palm (Phoenix dactylifera L.) cultivar's fruits growing in Dubai, United Arab Emirates, through high performance liquid chromatography. Journal of Saudi Chemical Society, 17(1), 9-16. http://dx.doi.org/10.1016/j.jscs.2011.02.015.

Association of Official Analytical Chemists - AOAC. (2000). Official method 942.15: acidity (titrable) of fruit products. Arlington: AOAC.

Belay, A., Ture, K., Redi, M., \& Asfaw, A. (2008). Measurement of caffeine in coffee beans with UV/Vis spectrophotometer. Food Chemistry, 108(1), 310-315. http://dx.doi.org/10.1016/j.foodchem.2007.10.024.

Bravo, J., Juániz, I., Monente, C., Caemmerer, B., Kroh, L. W., De Peña, M. P., \& Cid, C. (2012). Evaluation of spent coffee obtained from the most common coffeemakers as a source of hydrophilic bioactive compounds. Journal of Agricultural and Food Chemistry, 60(51), 12565-12573. http://dx.doi.org/10.1021/jf3040594. PMid:23214450.

Camargo, M. R., \& Toledo, M. C. (1999). HPLC determination of caffeine in tea, chocolate products and carbonated beverages. Journal of the Science of Food and Agriculture, 79(13), 1861-1864. http:// dx.doi.org/10.1002/(SICI)1097-0010(199910)79:13<1861::AIDJSFA448>3.0.CO;2-Y.

Chandrasekaran, M., \& Bahkali, A. H. (2013). Valorization of date palm (Phoenix dactylifera) fruit processing by-products and wastes using bioprocess technology: review. Saudi Journal of Biological Sciences, 20(2), 105-120. http://dx.doi.org/10.1016/j.sjbs.2012.12.004. PMid:23961227.

Chareonthaikij, P., Uan-On, T., \& Prinyawiwatkul, W. (2016). Effects of pineapple pomace fibre on physicochemical properties of composite flour and dough, and consumer acceptance of fibre-enriched wheat bread. International Journal of Food Science \& Technology, 51(5), 1120-1129. http://dx.doi.org/10.1111/ijfs.13072.

Chonpracha, P., Gao, Y., Tuuri, G., \& Prinyawiwatkul, W. (2019). Possible brewed coffee. Journal of Food Science, 84(12), 3784-3792. http:// dx.doi.org/10.1111/1750-3841.14964. PMid:31763704.

Clapp, O., Morgan, M. Z., \& Fairchild, R. M. (2019). The top five selling UK energy drinks: implications for dental and general health. British Dental Journal, 226(7), 493-497. http://dx.doi.org/10.1038/s41415019-0114-0. PMid:30980003.

de Paula, J., \& Farah, A. (2019). Caffeine consumption through coffee: content in the beverage, metabolism, health benefits and risks. Beverages, 5(2), 37. http://dx.doi.org/10.3390/beverages5020037.

Eid, N., Enani, S., Walton, G., Corona, G., Costabile, A., Gibson, G., Rowland, I., \& Spencer, J. P. E. (2014). The impact of date palm fruits and their component polyphenols, on gut microbial ecology, bacterial metabolites and colon cancer cell proliferation. Journal of Nutritional Science, 3, e46. http://dx.doi.org/10.1017/jns.2014.16. PMid:26101614.

El-Nimr, N. A., Bassiouny, S. H., \& Tayel, D. I. (2019). Pattern of caffeine consumption among university students. Journal of High Institute of Public Health, 49(3), 154-161. http://dx.doi.org/10.21608/jhiph.2019.56579.

Enyart, D. S., Crocker, C. L., Stansell, J. R., Cutrone, M., Dintino, M. M., Kinsey, S. T., Brown, S. L., \& Baumgarner, B. L. (2020). Lowdose caffeine administration increases fatty acid utilization and mitochondrial turnover in C2C12 skeletal myotubes. Physiological Reports, 8(1), e14340. http://dx.doi.org/10.14814/phy2.14340. PMid:31960608.

Food and Agriculture Organization of the United Nations - FAO, Codex Alimentarius Commission. (2005). CODEX general standard for fruit juices and nectars. Rome: Joint FAO/WHO Food Standards Programme. Retrieved from http://www.fao.org/tempref/codex/ Meetings/TFFJ/ccfvj1/cl00_01e.pdf

Food and Agriculture Organization of the United Nations - FAO. (2018). Crop production, statistics, division. Rome: FAO. Retrieved from http://faostat.fao.org

Higgins, J. P., Yarlagadda, S., \& Yang, B. (2015). Cardiovascular complications of energy drinks. Beverages, 1(2), 104-126. http:// dx.doi.org/10.3390/beverages1020104.

Ikeda, M., Akiyama, M., Hirano, Y., Miyazi, K., Kono, M., Imayoshi, Y., Iwabuchi, H., Onodera, T., \& Toko, K. (2018). Effects of processing conditions during manufacture on retronasal-aroma compounds from a milk coffee drink. Journal of Food Science, 83(3), 605-616. http://dx.doi.org/10.1111/1750-3841.14054. PMid:29412462.

Jahrami, H., Al-Mutarid, M., Penson, P. E., Al-Islam Faris, M., Saif, Z., \& Hammad, L. (2020). Intake of caffeine and its association with physical and mental health status among university students in Bahrain. Foods, 9(4), 473. http://dx.doi.org/10.3390/foods9040473. PMid:32290044.

Khalid, A., Ahmad, S., Raza, H., Batool, M., Lodhi, R. K., Ain, Q. T., \& Naseer, F. (2016). Determination of caffeine in soft and energy drinks available in market by using UV/visible spectrophotometer. Family Medicine \& Medical Science Research, 5(4), 1000206. http:// dx.doi.org/10.4172/2327-4972.1000206.

Krol, K., Gantner, M., Tatarak, A., \& Hallmann, E. (2020). The content of polyphenols in coffee beans as roasting, origin and storage effect. European Food Research and Technology, 246(1), 33-39. http://dx.doi. org/10.1007/s00217-019-03388-9.

Ludwig, T. G., \& Goldberg, H. J. V. (1956). The anthrone method for the determination of carbohydrates in foods and in oral rinsing. Journal of Dental Research, 35(1), 90-94. http://dx.doi.org/10.1177 /00220345560350012301. PMid:13286391.

Márquez Cardozo, C. J., Jiménez Castañeda, C. A., \& Salazar Ripoll, C. S. (2017). Development of mango (Mangifera indica L.) energy drinks. Revista Facultad Nacional de Agronomía, 70(1), 8115-8121. http://dx.doi.org/10.15446/rfna.v70n1.61770.

Melo Pereira, G. V., Carvalho, D. P. No., Magalhães, A. I. Jr., Vásquez, Z. S., Medeiros, A. B. P., Vandenberghe, L. P. S., \& Soccol, C. R. (2019). Exploring the impacts of postharvest processing on the aroma formation of coffee beans: a review. Food Chemistry, 272, 441-452. http://dx.doi.org/10.1016/j.foodchem.2018.08.061. PMid:30309567.

Miller, G. L. (1959). Use of dinitrosalisylic acid reagent for determination of reducing sugar. Analytical Chemistry, 31(3), 426-428. http://dx.doi. org/10.1021/ac60147a030.

Nadir, A., Abdelmagau, N. M., Helmy, I. M. F., \& Moawad, R. K. (2017). Physio-chemical and quality characteristics for date juice at Khalal stage. Asian Journal of Science Research, 10(4), 308-315. http://dx.doi. org/10.3923/ajsr.2017.308.315.

Nguyen, Q. V., \& Chuyen, H. V. (2020). Processing of herbal tea from roselle (Hibiscus sabdara L.): effects of drying temperature and brewing conditions on total soluble solid, phenolic content, antioxidant capacity and sensory quality. Beverages, 6(1), 2. http:// dx.doi.org/10.3390/beverages6010002. 
Nowak, D., \& Goslinski, M. (2020). Assessment of antioxidant properties of classic energy drinks in comparison with fruit energy drinks. Foods, 9(1), 56. http://dx.doi.org/10.3390/foods9010056. PMid:31935989.

Pilipczuk, T., Kusznierewicz, B., Zielinska, D., \& Bartoszek, A. (2015). The influence of roasting and additional processing on the content of bioactive components in special purpose coffees. Journal of Food Science and Technology, 52(9), 5736-5744. http://dx.doi.org/10.1007/ s13197-014-1646-6. PMid:26344987.

Sanchez, J. M. (2017). Methylxanthine content in commonly consumed foods in Spain and determination of its intake during consumption. Foods, 6(12), 109. http://dx.doi.org/10.3390/foods6120109. PMid:29207513.

Seninde, D. R., \& Chambers, E. 4th (2020). Coffee flavor: a review. Beverages, 6(3), 44. http://dx.doi.org/10.3390/beverages6030044.

Tayel, D. I., Abo-Rhyem, S. M., \& Tawfik, D. (2018). Caffeine content of products in Egyptian markets and its daily intake among Alexandria University employees. International Journal of Food Sciences and Nutrition, 3, 14-21.
Temple, J. L., Bernard, C., Lipshultz, S. E., Czachor, J. D., Westphal, J. A., \& Mestre, M. A. (2017). The safety of ingested caffeine: a comprehensive review. Frontiers in Psychiatry, 8, 80. http://dx.doi. org/10.3389/fpsyt.2017.00080. PMid:28603504.

Tfouni, S. A. V., Camara, M. M., Kamikata, K., Gomes, F. M. L., \& Furlani, R. P. Z. (2018). Caffeine in teas: levels, transference to infusion and estimated intake. Food Science and Technology, 38(4), 661-666. http://dx.doi.org/10.1590/1678-457x.12217.

United States Department of Agriculture - USDA. (2018). USDA National Nutrient Database-Caffeine. Retrieved from www.nal.usda.gov

Vignoli, J. A., Bassoli, D. G., \& Benassi, M. T. (2011). Antioxidant activity, polyphenols, caffeine and melanoidins in soluble coffee: the influence of processing conditions and raw material. Food Chemistry, 124(3), 863-868. http://dx.doi.org/10.1016/j.foodchem.2010.07.008.

Volpe, S. L. (2007). Micronutrient requirements for athletes. Clinics in Sports Medicine, 26(1), 119-130. http://dx.doi.org/10.1016/j. csm.2006.11.009. PMid:17241918. 